\title{
The association of polymorphisms of TLR4 and CD14 genes with susceptibility to sepsis in a Chinese population
}

\author{
Haiyan Wang ${ }^{1}$, Yesheng Wei ${ }^{1}$, Yi Zeng ${ }^{1}$, Yueqiu Qin ${ }^{1}$, Bin Xiong ${ }^{2}$, Gang Qin³ ${ }^{3}$ Jun Li', Donghai Hu', Xiaowen Qiu',
} Suren R Sooranna ${ }^{4}$ and Liao Pinhu ${ }^{1 *}$

\begin{abstract}
Background: Sepsis is now the leading cause of death in the non-cardiovascular intensive care unit (ICU). Recent research suggests that sepsis is likely to be due to an interaction between genetic and environmental factors. Genetic mutations of toll-like receptor 4 (TLR4) and cluster of differentiation 14 (CD14) genes are involved in the immune and (or) inflammatory response. These may contribute to the susceptibility to sepsis in patients. This study was designed to evaluate whether the TLR4 and cluster CD14 gene polymorphisms are associated with susceptibility to sepsis.

Methods: The single nucleotide polymorphisms (SNPs) of TLR4 (rs10759932, rs11536889, rs7873784, rs12377632, rs1927907, rs1153879) and CD14 (rs2569190 and rs2563298) in patients with sepsis and control subjects in the Guangxi Province were analyzed by using the polymerase chain reaction-single base extension (PCR-SBE) and DNA sequencing methods.

Results: The rs 11536889 polymorphism in TLR4 and rs2563298 polymorphism in CD14 were significantly associated with the risk of sepsis when compared to the control group. The frequencies of rs 11536889 and rs 2563298 polymorphisms in the group with sepsis were higher than that in the control group $(O R=1.430,95 \% \mathrm{Cl}, 1.032-1.981$, $P<0.05 ; O R=2.454,95 \% C l, 1.458-4.130, P<0.05$, respectively). Followed up haplotype analysis suggested that there were two haplotypes in which increased risk factors for sepsis were indicated.
\end{abstract}

Conclusions: The rs 11536889 polymorphism in TLR4 and rs2563298 polymorphism in CD14, and two haplotypes were associated with increased susceptibility to sepsis.

Keywords: Sepsis, Single nucleotide polymorphism, TLR4, CD14

\section{Background}

Sepsis is a clinical, catastrophic condition whereby pathogenic microorganisms are able to trigger in the host, the immune and coagulation systems as well as apoptosis which result in systemic inflammatory response syndrome (SIRS). In response to infection, increased amounts of proinflammatory and antiinflammatory mediators are released. The imbalance between proinflammatory and antiinflammatory effectors may lead to cell and tissue injury

\footnotetext{
* Correspondence: liaopinhu@163.com

${ }^{1}$ Intensive Care Medicine, Affiliated Hospital of Youjiang Medical University for Nationalities, No.18 Zhongshan Road II, Baise 533099, Guangxi, PR China Full list of author information is available at the end of the article
}

as well as organ function disorder, which can results in a series of serious medical complications [1].

Despite significant advances in intensive care, improved supportive measures and popularized evidence-based guidelines, the prognosis for sepsis is still not ideal, and severe sepsis and septic shock are also the leading causes of death in the non-cardiovascular intensive care unit, even in developed countries [2].

Patients with similar general clinical symptoms and infected with the same microorganisms and undergoing similar therapy could present with different clinical outcomes, which indicate that genetic factors may be involved in these processes [3,4]. Research evidence suggests that sepsis is likely to be due to an interaction of genetic and 
environmental factors [5-7]. Genetic factors may affect the body's response to infection caused by microorganisms. Genetic mutation in genes involved in the immune and (or) inflammatory response may contribute to the susceptibility to sepsis [6]. This may explain the clinical variability observed during similar infections. The infection-triggered systemic inflammatory response plays a critical role in the pathogenesis of sepsis $[8,9]$. The immune response is the first-line response to defense microbial infections. Pattern recognition receptors (PRRs) are essential for triggering the immune response and these include the TLR gene family. These receptors can recognize molecules expressed on the surface of microorganisms, which are called pathogen-associated molecular patterns (PAMPs). It is postulated that SNPs in these receptors may influence their ability to recognize microorganisms [10].

TLRs are an evolutionarily conserved family of receptors which play fundamental roles in pathogen recognition and the innate immune and inflammatory response [11-14]. TLRs have three functional domains within their structures: an ectodomain, which contains multiple leucinerich repeats (LRR) participating in the recognition and binding of pathogens, a cytoplasmic domain that also spans the membrane and a toll/interleukin-1 receptor (TIR) domain. To date thirteen members of the TLR family have been identified [15]. TLR4 is one of the TLR family members that has been the widely most investigated. The gene encoding for human TLR4 is mapped on chromosome 9q32-33 and includes 3 exons and 2 introns. TLR4 can recognize a variety of pathogens, including Gram-negative and Gram-positive bacteria [16], fungi [17], viruses [18] and protozoa [19]. CD14 is a coreceptor that contributes to TLR-induced cell activation. Upon binding to the microbial ligands, $C D 14$ becomes linked to TLR4 and then, TLR4 can activate downstream signaling transduction pathways, such as the nuclear factor-kappa B (NF-kB) signaling pathway. This subsequently mediates the production of cytokines, chemokines and coagulation factors which are involved in the pathological process of inflammation [12,20].

It has been reported that some polymorphisms in the TLR4 and CD14 genes may regulate their expression, thereby, influencing the production of TLR4 [21] and $C D 14[22,23]$. Several studies have shown that polymorphisms in TLR4 and CD14 genes may relate to the susceptibility with some infection induced diseases, e.g. sepsis [24-28], but this is controversial.

In this study, we investigated the relationship between sepsis and TLR4 gene rs10759932, rs11536889, rs7873784, rs12377632, rs1927907 and rs1153879 polymorphisms as well as CD14 gene rs2563298 and rs2569190 polymorphisms in a Chinese population. Genotyping analysis of eight SNPs in TLR4 and CD14 genes were performed by using Snapshot SNP genotyping assays and DNA sequencing methods to investigate whether the gene polymorphisms are associated with susceptibility to sepsis.

\section{Methods}

\section{Study subjects}

The clinical characteristics of the study subjects are shown in Table 1 . One hundred and fifty-two patients (48 females and 104 males) from the ages of 18 to 80 years (average age- $55.47 \pm 16.48$ ) with sepsis were recruited for this study between July 2011 and December 2012 in the ICU of the Affiliated Hospital of Youjiang Medical University for Nationalities, Guangxi, PR China. The inclusion criteria were according to the American College of Chest Physicians/Society of Critical Care Medicine (ACCP/SCCM) criteria for sepsis, severe sepsis, or septic shock. Exclusion criteria were: 1. patients younger than 18 or older than 80 years old; 2 . cardiac arrest; 3. emergency surgery; 4. receiving an immunosuppressive therapy. In addition, patients from whom consent could not be obtained were excluded from the study.

The control subjects underwent a routine medical check-up in the outpatient clinic of the Department of Internal Medicine, Affiliated Hospital of Youjiang Medical University for Nationalities, Guangxi, China between July 2011 and December 2012. According to the thorough clinical and laboratory evaluation, none of them was

Table 1 The clinical characteristics of the study subjects

\begin{tabular}{lll}
\hline Parameters & Cases $(\mathbf{n}=\mathbf{1 5 2})$ & Controls $(\mathbf{n}=\mathbf{1 9 9})$ \\
\hline Age & $55.47 \pm 16.48$ & $53.93 \pm 14.45$ \\
Male & 104 & 118 \\
Female & 48 & 81 \\
Site of infection & & \\
Lung & 80 & \\
Abdomen & 51 & \\
Blood & 10 \\
Undefined site & 11 \\
Co-morbidities & \\
Hypertension & 20 & \\
Diabetes & 15 \\
Renal dysfunction & 5 & \\
Liver dysfunction & 4 & \\
ARDS & 6 \\
COPD & 7 & \\
Sepsis & 17 \\
Severe sepsis & 115 \\
Septic shock & 20 \\
APACHEll & $20.5 \pm 6.4$ \\
\hline
\end{tabular}


found to have any medical condition other than infection, history of cardiac arrest or receiving an immunosuppressive therapy. One hundred and ninety-nine control subjects from similar ethnic background, age and gender (81 females and 118 males, aged between 25 and 80 years) were also studied. The protocol used for the study was approved by the Local Ethical Committee of Youjiang Medical University of Medical Sciences, and written informed consent was obtained from all participants. All participating subjects were of Guangxi origin.

\section{DNA extraction and PCR assay}

$5 \mathrm{~mL}$ of venous blood was collected from each patient for genetic studies. Genomic DNA was extracted from whole peripheral blood using a QIA Amp DNA Blood Mini Kit (Qiagen, Germany) according to the standard protocols. The DNA was subsequently stored at $-20^{\circ} \mathrm{C}$ until needed. Before use, the DNA was resolved using a $1 \%$ agarose gel stained with the ethidium bromide.
The following sequences obtained from GenBank were used as reference sequences for TLR4 (Gene ID: 7099): NG_011475.1: 4994-18310 (genomic) and CD14 (Gene ID: 929): NG_023178.1: 5001-6974 (genomic). PCR primers were designed using Primer 3 Input (version 0.4.0; Table 2). The PCR reactions consisted of $1 \mathrm{x}$ HotStart Taq buffer, $3.0 \mathrm{mM}$ magnesium chloride, $0.3 \mathrm{mM}$ dNTP mixture, $1 \mathrm{U}$ HotStart Taq polymerase, forward and reverse primer mixtures and genomic DNA. The PCR conditions were as follows: $95^{\circ} \mathrm{C}$ for $2 \mathrm{~min}$, followed by 11 cycles of: $94^{\circ} \mathrm{C}$ for $20 \mathrm{sec}$, annealing temperature depending on the primer, $72^{\circ} \mathrm{C}$ for $90 \mathrm{sec}, 24$ cycles of: $94^{\circ} \mathrm{C}$ for $20 \mathrm{sec}, 59^{\circ} \mathrm{C}$ for $30 \mathrm{sec}, 72^{\circ} \mathrm{C}$ for $90 \mathrm{sec}$, and then $72^{\circ} \mathrm{C}$ for $2 \mathrm{~min}$ followed by $4^{\circ} \mathrm{C}$ until the reaction mixtures were removed from the cycler.

\section{Genotyping procedure}

PCR products were sequenced using the ABI PRISM SNaPshot Multiplex Kit according to the protocols. Detection and sequencing were carried out with a 3730XL

Table 2 The primer sequences used for detecting the different TLR4 and CD14 SNPs

\begin{tabular}{|c|c|}
\hline SNP ID & PCR primers \\
\hline \multicolumn{2}{|l|}{ TLR4 } \\
\hline \multirow[t]{3}{*}{ rs10759932 } & F: 5'-TGCAAGCTTCTGCTATGATTAAAAGTGAT-3' \\
\hline & R: 5'-TCATGGACACTTGCATTGTTGC-3' \\
\hline & EF: 5'-TTITITITITITGAGTTCTCATTITITCACATCTTCACCAAC-3' \\
\hline \multirow[t]{3}{*}{ rs12377632 } & F: 5'-TCCCCAGGGTCTATITITGTCATC-3' \\
\hline & R: 5'-GGGAAGCTGGCCTCTCTGTAAGC-3' \\
\hline & EF: 5'-TTITTITTITTITITCAAGTACTCTATTAAGGTAGACCACCTCTCCC-3' \\
\hline \multirow[t]{3}{*}{ rs1927907 } & F: 5'-TCCCCAGGGTCTATTITTGTCATC-3' \\
\hline & R: 5'-GGGAAGCTGGCCTCTCTGTAAGC-3' \\
\hline & EF: 5'-TTाTाTाTाTाTाTाTाTाTGAAGATGAATTACATAAGAGACATTGTTR-3' \\
\hline \multirow[t]{3}{*}{ rs11536879 } & F: 5'-CCTGTTGGGGTCAGAAGACCTG-3' \\
\hline & R: 5'-TCGATTGTACCCTACACCTCAGCATTA-3' \\
\hline & EF: 5'-TTाTाTाTाIIITIIIIITTATAAGTTTCATCATTTCCATTGATCAGATA-3' \\
\hline \multirow[t]{3}{*}{ rs11536889 } & F: 5'-GCTGGGATCCCTCCCCTGTA-3' \\
\hline & R: 5'-TGGGAACCTTCTTTATAAGAACCCCATTA-3' \\
\hline & 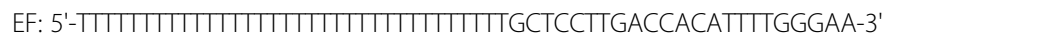 \\
\hline \multirow[t]{3}{*}{ rs7873784 } & F: 5'-GGTTCCTAGGGAAAAGGAGGAAGG-3' \\
\hline & R: 5'-CATCACCTCCAAAAGCTTCCTTG-3' \\
\hline & EF: 5'-TाIIIIIIIIIIIIIIIIIIIIIIIIIITAGCTCTAAAGATCAGCTGTATAGCAGAGTTY-3' \\
\hline \multicolumn{2}{|l|}{ CD14 } \\
\hline \multirow[t]{3}{*}{ rs2569190 } & F: 5'-TCTTCGGCTGCCTCTGACAGTT-3' \\
\hline & R: 5'-TTTTCCCACACCCACCAGAGAA-3' \\
\hline & EF: 5'-TITITITITTCCTGCAGAATCCTTCCTGTTACGG-3' \\
\hline \multirow[t]{3}{*}{ rs2563298 } & F: 5'-TGAATTCCCCATCCAGCACTGT-3' \\
\hline & R: 5'-CTTCCTGGTCCCTGGAACTGC-3' \\
\hline & EF:5'-TाTाTाTाTाTाTाTाTाTाTाTाTाTाTाTाTाCCCCACCTITATTAAAATCTTAAACAACGG-3' \\
\hline
\end{tabular}

F: forward, R: reverse, E: extension. 
ABI Genetic Analyzer. Results were analyzed using GeneMapper 4.1 (Applied Biosystems Co., Ltd., USA).

\section{Statistical analysis}

Quanto software was used to estimate the adequate sample size for our study. The relative risk was set to 1.30 and the statistical power was more than $80 \%$. Demographic and clinical data between sepsis cases and controls were compared by chi-square test ( $\chi^{2}$ test) and by Student's t-test. The differences in genotype and allele frequencies of TLR4 and CD14 were compared among the groups using the $\chi^{2}$ test and when appropriate, Fisher's exact test (two-sided analysis) was used as indicated. Odds ratios (OR) and 95\% confidence intervals (CIs) were calculated to assess the relative risk conferred by a particular allele and genotype. Hardy-Weinberg equilibrium analysis was tested by comparing the detected genotype distribution with the theoretical distribution estimated on the basis of the allele frequencies in the control group (Table 3). The linkage disequilibrium (LD) among SNPs of the TLR4 gene or the CD14 gene was examined by pair-wise comparisons of D' using Haploview, version 4.1. The haplotypes and their frequencies were estimated based on a Bayesian algorithm using the Phase program [29]. No correction for multiple testing was performed during analysis of the data. All reported $p$ values were two-tailed and $p<0.05$ was considered to be significant. The SPSS statistical software package version 13.0 was used for statistical analysis.

\section{Results}

One hundred fifty-two patients with sepsis and one hundred ninety-nine control subjects were genotyped. The genotypic and allelic frequencies for SNPs are shown in Table 4. The frequency of all genotypes studied did not reveal any difference using the Hardy-Weinberg equilibrium analysis in control groups $(p>0.05)$.

As shown in Table 4, a statistical significance was observed between rs11536889 in TLR4 gene and rs2563298 in CD14 gene in patients with sepsis and controls. The genotype frequency of rs11536889 indicated a trend of higher frequency of $\mathrm{GC}+\mathrm{CC}$ in the sepsis patients $(p=0.009<0.05)$, [OR and 95\% CI: $1.758(1.147-2.695)]$. The $\mathrm{C}$ allele was significantly associated with susceptibility to sepsis $(p=0.031<0.05)[O R$ and 95\% CI: 1.430 (1.0321.981)]. Compared to healthy controls, the rs 2563298 was significantly associated with a risk of sepsis, and the frequencies of the CC, CA and AA genotypes of rs 2563298 were $86.8 \%, 12.5 \%$ and $0.7 \%$ in cases of sepsis and were $71.2 \%, 26.8 \%$ and $2.0 \%$ in control subjects, respectively. The $\mathrm{C}$ allele was associated with a significantly increased risk of sepsis as compared with the A allele $(p=0.001<0.05)$ [OR and 95\% CI: 2.454 (1.458-4.130)].

Figure 1 shows the pair-wise LD of the SNPs of TLR4 and $C D 14$ genes in patients with sepsis. The haplotype frequency of the eight SNPs of TLR4 gene and two SNPs of CD14 gene were estimated. For the TLR4 gene, there were eleven SNP haplotypes detected, and only four had

Table 3 Hardy-Weinberg equilibrium analysis

\begin{tabular}{|c|c|c|c|c|c|c|c|c|}
\hline \multirow[t]{2}{*}{ Polymorphism } & \multicolumn{3}{|c|}{ Actual distribution } & \multicolumn{3}{|c|}{ Theoretical distribution } & \multirow[t]{2}{*}{$x^{2}$} & \multirow[t]{2}{*}{$P$} \\
\hline & \multicolumn{3}{|c|}{ Genotypes } & \multicolumn{3}{|c|}{ Genotypes } & & \\
\hline \multicolumn{9}{|l|}{ TLR4 } \\
\hline & $\mathrm{CC}$ & CT & $\pi$ & CC & CT & $\pi$ & & \\
\hline \multirow[t]{2}{*}{ rs10759932(T/C) } & 7 & 62 & 130 & 7.26 & 61.49 & 130.26 & 0.014 & 0.993 \\
\hline & $\mathrm{AA}$ & GA & GG & AA & GA & GG & & \\
\hline \multirow[t]{2}{*}{ rs12377632(C/T) } & 19 & 94 & 86 & 21.89 & 88.22 & 88.89 & 0.854 & 0.653 \\
\hline & $\mathrm{CC}$ & $\mathrm{CT}$ & $\pi$ & $\mathrm{CC}$ & CT & $\pi$ & & \\
\hline \multirow[t]{2}{*}{ rs1927907(C/T) } & 136 & 47 & 5 & 135.32 & 48.36 & 4.32 & 0.148 & 0.928 \\
\hline & $\mathrm{AA}$ & GA & GG & $\mathrm{AA}$ & GA & GG & & \\
\hline \multirow[t]{2}{*}{ rs11536879(A/G) } & 145 & 48 & 3 & 145.72 & 46.56 & 3.72 & 0.187 & 0.911 \\
\hline & CC & GC & GG & $\mathrm{CC}$ & GC & GG & & \\
\hline \multirow[t]{2}{*}{ rs11536889(G/C) } & 15 & 75 & 109 & 13.85 & 77.30 & 107.85 & 0.176 & 0.916 \\
\hline & $\mathrm{CC}$ & $C G$ & GG & CC & $C G$ & GG & & \\
\hline rs7873784(G/C) & 2 & 39 & 157 & 2.33 & 38.33 & 157.33 & 0.060 & 0.970 \\
\hline \multicolumn{9}{|l|}{ CD14 } \\
\hline & AA & GA & GG & AA & GA & GG & & \\
\hline \multirow[t]{2}{*}{ rs2569190(A/G) } & 65 & 87 & 45 & 59.76 & 97.48 & 39.76 & 2.279 & 0.320 \\
\hline & $\mathrm{AA}$ & CA & CC & $\mathrm{AA}$ & CA & $\mathrm{CC}$ & & \\
\hline rs2563298(C/A) & 4 & 53 & 141 & 4.70 & 51.60 & 141.70 & 0.145 & 0.930 \\
\hline
\end{tabular}


Table 4 The genotype and allele frequencies of patients with sepsis and controls

\begin{tabular}{|c|c|c|c|c|c|c|c|c|c|}
\hline \multirow[t]{2}{*}{ Polymorphism } & \multicolumn{3}{|c|}{ Genotypes } & \multirow[t]{2}{*}{$x^{2}$} & \multirow[t]{2}{*}{$P$} & \multicolumn{2}{|c|}{ Alleles } & \multirow[t]{2}{*}{$O R(95 \% \mathrm{Cl})$} & \multirow[t]{2}{*}{$P$} \\
\hline & $\overline{11}$ & 12 & 22 & & & 1 & 2 & & \\
\hline \multicolumn{10}{|l|}{ TLR4 } \\
\hline rs10759932(T/C) & $\Pi$ & TC & $\mathrm{CC}$ & & & T & C & & \\
\hline Controls & 130 & 62 & 7 & 0.987 & 0.611 & 322 & 76 & $0.874(0.592-1.290)$ & 0.499 \\
\hline Cases & 106 & 40 & 6 & & & 252 & 52 & & \\
\hline rs12377632(C/T) & CC & $\mathrm{CT}$ & $\pi$ & & & C & $\mathrm{T}$ & & \\
\hline Controls & 86 & 94 & 19 & 0.433 & 0.805 & 266 & 132 & $0.916(0.665-1.261)$ & 0.591 \\
\hline Cases & 71 & 67 & 14 & & & 209 & 95 & & \\
\hline rs1927907(C/T) & CC & CT & $\pi$ & & & C & $\mathrm{T}$ & & \\
\hline Controls & 136 & 47 & 5 & 0.499 & 0.802 & 319 & 57 & $1.075(0.710-1.630)$ & 0.732 \\
\hline Cases & 109 & 37 & 6 & & & 255 & 49 & & \\
\hline rs11536879(A/G) & AA & $A G$ & GG & & & A & G & & \\
\hline Controls & 145 & 48 & 3 & 0.756 & 0.72 & 338 & 54 & $1.031(0.670-1.588)$ & 0.889 \\
\hline Cases & 110 & 41 & 1 & & & 261 & 43 & & \\
\hline rs11536889(G/C) & GG & GC & $\mathrm{CC}$ & & & G & C & & \\
\hline Controls & 109 & 75 & 15 & 6.918 & 0.031 & 293 & 105 & $1.430(1.032-1.981)$ & 0.031 \\
\hline Cases & 62 & 77 & 13 & & & 201 & 103 & & \\
\hline rs7873784(G/C) & GG & GC & CC & & & G & C & & \\
\hline Controls & 157 & 39 & 2 & 0.616 & 0.752 & 353 & 43 & $1.173(0.737-1.866)$ & 0.501 \\
\hline Cases & 116 & 34 & 2 & & & 266 & 38 & & \\
\hline \multicolumn{10}{|l|}{ CD14 } \\
\hline rs2569190(A/G) & AA & AG & GG & & & A & G & & \\
\hline Controls & 65 & 87 & 45 & 3.973 & 0.137 & 217 & 177 & $1.322(0.975-1.793)$ & 0.073 \\
\hline Cases & 58 & 72 & 22 & & & 188 & 116 & & \\
\hline rs2563298(C/A) & $C C$ & CA & AA & & & C & A & & \\
\hline Controls & 141 & 53 & 4 & 12.41 & 0.001 & 335 & 61 & $2.454(1.458-4.130)$ & 0.001 \\
\hline Cases & 132 & 19 & 1 & & & 283 & 21 & & \\
\hline
\end{tabular}

No correction for multiple testing was performed during analysis of the data.

frequencies greater than $5 \%$ (Table 5 ). As shown in Table 5 , the results indicate that one haplotype (TACCCG) contributed to a significant difference $(p=0.006<0.05)[O R$ and 95\% CI: $1.590(1.143-2.211)]$, which therefore shows that this haplotype serves as an increase risk factor for sepsis. The other haplotypes were not associated with susceptibility to sepsis. As for the CD14 gene, there were four SNP haplotypes detected (Table 6). Compared to controls, the haplotype AG was significantly different $(p=0.001<0.05)$ [OR and 95\% CI: $0.410(0.244-0.690)]$, and this seems to provide a protective role in sepsis.

\section{Discussion}

In this study, we investigated the association of TLR4 gene and CD14 gene SNPs (TLR4: rs10759932, rs11536889, rs7873784, rs12377632, rs1927907, rs1153879 and CD14: rs2563298, rs2569190) with susceptibility to sepsis. Our results demonstrate that statistically significant associations with risk of sepsis were observed for the candidate rs11536889 SNP of TLR4 gene, rs2563298 SNP of CD14 gene and two haplotypes.

TLR4 is a type I transmembrane protein which plays a key role in host defense mechanisms by activating both innate and adaptive immunity against pathogenic microbial infections such as Escherichia coli, Klebsiella pneumoniae, Staphylococcus aureus, Acinetobacter baumannii and Pseudomonas aeruginosa [30,31]. It plays an important role in some immune and inflammatory diseases. Several studies have reported a functional significance of TLR4 gene polymorphisms. Previous studies had reported that two SNPs of the TLR4 gene, which are located in promoter region, could lead to hyporesponsiveness to lipopolysaccharide (LPS) [32,33]. The possible involvement of these SNPs in the development of sepsis has been widely reported $[17,24,25,34]$. However, the distribution of these SNPs is rare in the Chinese $[35,36]$ as well as in the general 


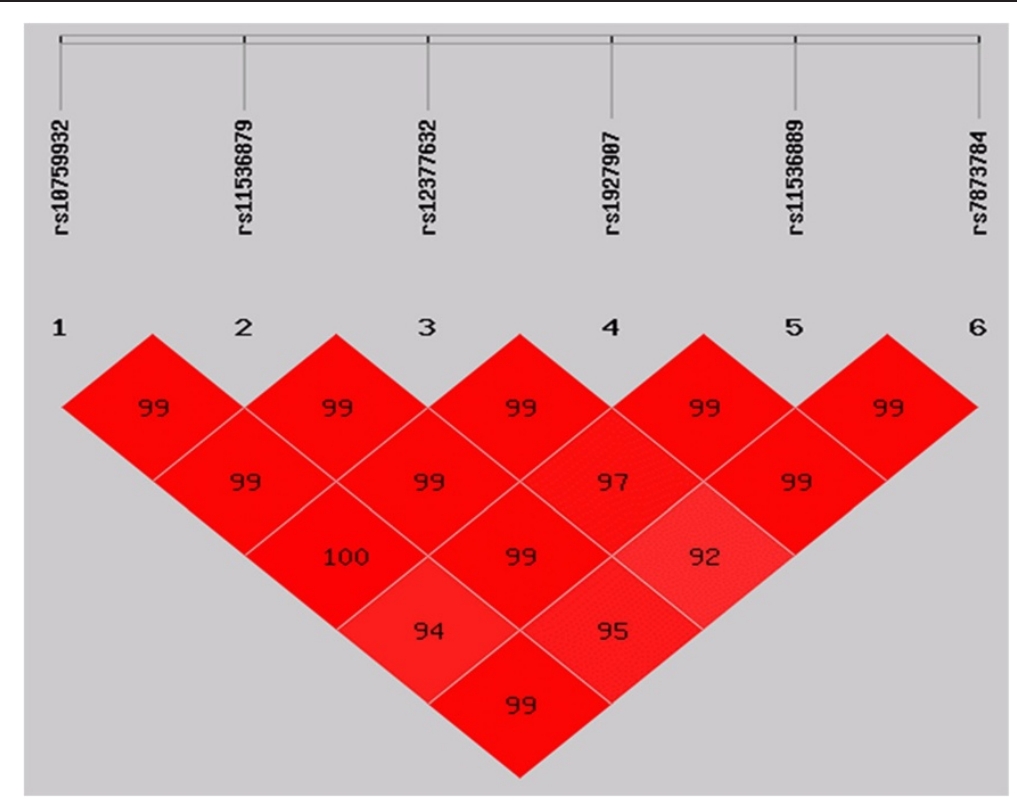

Figure 1 Linkage disequilibrium plot of six SNPs of the TLR4 gene in patients with sepsis. $D^{\prime}$ corresponding to each SNP pair is expressed as a percentage and shown within the respective squares. Higher $D^{\prime}$ is indicated by a brighter red colour.

Asian population. Our results show that frequency of the $\mathrm{GC}+\mathrm{CC}$ genotype rs11536889, which is located in the 3'untranslated region, is higher in the sepsis group when compared to the controls. With the present study, there is no evidence that rs10759932, rs7873784, rs12377632, rs1927907 and rs1153879 are associated with susceptibility to sepsis. By haplotype analysis, it was found that the TACCCG haplotype was associated with a significantly increased risk of sepsis when compared with the control group.

Fukusaki et al. [37] suggested that CC genotype rs11536889 was associated with moderate and severe

\section{Table 5 Haplotype distribution of TLR4 in patients with} sepsis and controls

\begin{tabular}{llllll}
\hline Haplotypes & Cases & Controls & \multicolumn{1}{l}{$\mathbf{2}$} & $\boldsymbol{P}$ & OR (95\%) \\
\hline CATTGG & 49 & 55 & 0.722 & 0.395 & $1.198(0.789-1.820)$ \\
TACCCG & 103 & 97 & 7.651 & 0.006 & $1.590(1.143-2.211)$ \\
TACCGG & 104 & 152 & 1.179 & 0.278 & $0.842(0.616-1.149)$ \\
TGTCGC & 36 & 38 & 0.962 & 0.327 & $1.273(0.785-2.062)$ \\
TGTCGG & 7 & 13 & 0.578 & 0.447 & $0.698(0.275-1.771)$ \\
CATCCG & 0 & 1 & - & - & - \\
CATCGG & 3 & 10 & - & - & - \\
CATTCG & 0 & 0 & - & - & - \\
TACCGC & 2 & 1 & - & - & - \\
TATCGG & 0 & 1 & - & - & - \\
TGTCCC & 0 & 0 & - & - & - \\
\hline
\end{tabular}

From left to right: rs10759932 T/C; rs11536879 A/G; rs12377632 C/T; rs1927907 $\mathrm{C} / \mathrm{T} ; \mathrm{rs} 11536889 \mathrm{G} / \mathrm{C}$ and rs $7873784 \mathrm{G} / \mathrm{C}$. periodontitis in the Japanese population. Hishida et al. $[38,39]$ have shown that GC + CC genotype rs11536889 may be associated with severe gastric atrophy related to Helicobacter pylori infection. Zhou et al. [40] examined whether polymorphisms of the TLRs genes were associated with hepatitis $B$ virus recurrence after liver transplantation. They showed a significant association of one SNP, namely rs11536889, with hepatitis B virus recurrence after liver transplantation. Hepatitis B virus recurrence after liver transplantation was higher than in the patients with the CC genotype when compared to other genotypes. Miedema et al. [41] found that rs11536889 polymorphism may be associated with an increased risk of developing chemotherapy-induced neutropenia. Sato et al. [21] investigated whether polymorphisms of rs 11536889 were associated with expression or function of TLR4. They found that TLR4 mRNA expression in PBMCs among GG, GC and CC genotypes did not significantly respond to LPS stimulation. However, the TLR4 protein expressed at the cell surface membrane was different. Therefore, it is possible that the $\mathrm{G}$ allele of rs11536889 may inhibit

Table 6 Haplotype distribution of CD14 in patients with sepsis and controls

\begin{tabular}{llllll}
\hline Haplotypes & Cases & Controls & $X 2$ & $P$ & OR(95\%) \\
\hline AG & 21 & 61 & 11.841 & 0.001 & $0.410(0.244-0.690)$ \\
CA & 188 & 217 & 3.783 & 0.052 & $1.252(0.997-1.832)$ \\
CG & 95 & 116 & 0.363 & 0.547 & $1.105(0.798-1.529)$ \\
AA & - & - & - & - & - \\
\hline From & & & & &
\end{tabular}

From left to right: rs2569190 A/G and rs2563298 C/A. 
translation rather than gene transcription in order to regulate the expression of the TLR4 gene. Meanwhile, this study shows that certain genotypes may affect the release of inflammatory cytokines. As shown by Mansur et al., polymorphism of rs11536889 can affect the clinical outcome of patients with sepsis. In addition, the $G$ allele of rs11536889 may increase the incidence of gram-negative infections [42].

$C D 14$ is also an important recognition receptor which plays a key role in the immune and inflammatory responses. Previous studies have shown that polymorphisms of $C D 14$ gene are involved with some inflammatory diseases, such as asthma [43], inflammatory bowel disease $[44,45]$, ulcerative colitis [44] and Crohn's disease [46]. Currently, most studies focused on the SNPs which were located within $C D 14$ gene promoter region. Results from previous studies have shown that these SNPs were associated with the prognosis of critically ill patients [47,48]. Studies have shown that genetic polymorphisms of these SNPs can affect $C D 14$ gene expression as well as the level of soluble CD14 in serum [22,23], and that this might be involved with the occurrence of sepsis and the subsequent prognosis of the disease [26,28]. However, these studies are not consistent. One meta-analysis evaluated the associated between $C D 14$ promoter $-159 \mathrm{C} / \mathrm{T}$ polymorphism and the risk of sepsis. The results demonstrated that this SNP is unlikely to be a risk factor for susceptibility to sepsis. Only a weak correlation was found in the Asian population [27]. This study also illustrates the importance of genetic background and environmental factors in establishing whether SNPs may be risk factors for susceptibility to sepsis.

Our results suggest that there is no evidence that rs2569190 is associated with susceptibility to sepsis. Compared to the control group, CC genotypes of rs2563298 in the sepsis group were significantly higher and the frequency of $\mathrm{C}$ allele in the sepsis group was also significantly higher. By haplotype analysis, it was found that the AG haplotype may be a protective factor to sepsis. Rs 2563298 is located in the 3'-untranslated region of the CD14 gene. This study is the first to assess the potential implications of $C D 14$ gene rs2563298 on susceptibility to sepsis. Previous studies suggested that SNPs in the 3'-untranslated region may have an important role in mRNA translation. Liu et al. [49] suggested that CD14 genetic polymorphisms may affect the length of CD14 transcripts or the efficiency protein translation, which could influence the function of CD14 and lead to a dysregulation of the immune response.

SNPs in the 3'-untranslated region probably have no direct effect on the primary structure (ie. amino acid sequence) of the protein. But the SNPs may change the function of 3'-end of mRNA or affect the mRNA stability in order to regulate target gene expression which may, in turn, affect the process of transmembrane conductance signals.

The observed association of higher susceptibility to sepsis among TLR4 rs11536889 and CD14 rs2563298 genotypes may help intensive care specialists to identify patients at risk of developing sepsis.

\section{Conclusions}

In summary, this study indicates that SNPs (TLR4: rs 11536889 and CD14: rs2563298) and two haplotypes are associated with susceptibility to sepsis in a Chinese population.

\section{Abbreviations}

CD14: Cluster of differentiation 14; PCR: Polymerase chain reaction; SNPs: Single nucleotide polymorphisms; TLR4: Toll-like receptor 4.

\section{Competing interests}

The authors do not have any conflicts of interest, financial or otherwise, to declare.

\section{Authors' contributions}

HW and LP designed the study and wrote the article; YW, YZ, YQ, DH, XQ and SRS carried out the molecular genetic studies and analyzed the data; BX, $G Q$, JL and LP collected the samples and participated in clinical data collection. All authors read and approved the final manuscript.

\section{Acknowledgements}

This work was supported by the National Natural Science Foundation of China (Grant No. 81060007), the Science and Technique Research Projects of Guangxi, No.1140003B-93 and the Key Programs of Natural Science Foundation of Guangxi, No.2011GXNSFD018039.

\section{Author details}

${ }^{1}$ Intensive Care Medicine, Affiliated Hospital of Youjiang Medical University for Nationalities, No.18 Zhongshan Road II, Baise 533099, Guangxi, PR China ${ }^{2}$ Intensive Care Unit, the People's Hospital of Guangxi Zhuang Autonomous Region, 6 Taoyuan Road, Nanning 530021, Guangxi, PR China. Intensive Care Unit, Minzu Hospital of Guangxi Zhuang Autonomous Region, 323 Mingxiu East Road, Nanning 530021, Guangxi, PR China. ${ }^{4}$ Department of Surgery and Cancer, Imperial College London, Chelsea and Westminster Hospital, London SW10 9NH, UK.

Received: 2 July 2014 Accepted: 23 October 2014

Published online: 14 November 2014

\section{References}

1. Horakova K, Chylkova A, Kolorz M, Bartosova L, Pechacek V, Starostka D, Wroblova K: Polymorphism G-308A in the promoter of the tumor necrosis factor-alpha gene and its association with the risk of venous thromboembolism. Blood Coagul Fibrinolysis 2012, 23(4):316-319.

2. Mayr FB, Yende S, Angus DC: Epidemiology of severe sepsis. Virulence 2014, 5(1):4-11.

3. Cooke GS, Hill AV: Genetics of susceptibility to human infectious disease. Nat Rev Genet 2001, 2(12):967-977.

4. Hill AV: The genomics and genetics of human infectious disease susceptibility. Annu Rev Genomics Hum Genet 2001, 2:373-400.

5. Barber RC, Aragaki CC, Chang LY, Purdue GF, Hunt JL, Arnoldo BD, Horton JW: CD14-159 C allele is associated with increased risk of mortality after burn injury. Shock 2007, 27(3):232-237.

6. Stanilova SA: Functional relevance of IL-10 promoter polymorphisms for sepsis development. Crit Care 2010, 14(1):119.

7. Teuffel $\mathrm{O}$, Ethier MC, Beyene J, Sung L: Association between tumor necrosis factor-alpha promoter $-308 \mathrm{~A} / \mathrm{G}$ polymorphism and susceptibility to sepsis and sepsis mortality: a systematic review and meta-analysis. Crit Care Med 2010, 38(1):276-282.

8. Fahy RJ, Exline MC, Gavrilin MA, Bhatt NY, Besecker BY, Sarkar A, Hollyfield JL, Duncan MD, Nagaraja HN, Knatz NL, Hall M, Wewers MD: Inflammasome 
mRNA expression in human monocytes during early septic shock. Am J Respir Crit Care Med 2008, 177(9):983-988.

9. Pachot A, Monneret G, Voirin N, Leissner P, Venet F, Bohe J, Payen D, Bienvenu J, Mougin B, Lepape A: Longitudinal study of cytokine and immune transcription factor mRNA expression in septic shock. Clin Immunol 2005, 114(1):61-69.

10. Agnese DM, Calvano JE, Hahm SJ, Coyle SM, Corbett SA, Calvano SE, Lowry SF: Human toll-like receptor 4 mutations but not CD14 polymorphisms are associated with an increased risk of gram-negative infections. J Infect Dis 2002, 186(10):1522-1525.

11. Akira S, Takeda K, Kaisho T: Toll-like receptors: critical proteins linking innate and acquired immunity. Nat Immunol 2001, 2(8):675-680.

12. Werling $D$, Jungi TW: TOLL-like receptors linking innate and adaptive immune response. Vet Immunol Immunopathol 2003, 91(1):1-12.

13. Kang SS, Kauls LS, Gaspari AA: Toll-like receptors: applications to dermatologic disease. J Am Acad Dermatol 2006, 54(6):951-983. quiz 983-956.

14. Arancibia SA, Beltran CJ, Aguirre IM, Silva P, Peralta AL, Malinarich F, Hermoso MA: Toll-like receptors are key participants in innate immune responses. Biol Res 2007, 40(2):97-112

15. Yang H, Wei C, Li Q, Shou T, Yang Y, Xiao C, Yu M, Li M, Yang Z, Zhang J, Zheng B: Association of TLR4 gene non-missense single nucleotide polymorphisms with rheumatoid arthritis in Chinese Han population. Rheumatol Int 2013, 33(5):1283-1288.

16. Aderem A, Ulevitch RJ: Toll-like receptors in the induction of the innate immune response. Nature 2000, 406(6797):782-787.

17. Van der Graaf CA, Netea MG, Morre SA, Den Heijer M, Verweij PE, Van der Meer JW, Kullberg BJ: Toll-like receptor 4 Asp299Gly/Thr399lle polymorphisms are a risk factor for Candida bloodstream infection. Eur Cytokine Netw 2006, 17(1):29-34.

18. Kurt-Jones EA, Popova L, Kwinn L, Haynes LM, Jones LP, Tripp RA, Walsh EE, Freeman MW, Golenbock DT, Anderson LJ, Finberg RW: Pattern recognition receptors TLR4 and CD14 mediate response to respiratory syncytial virus. Nat Immunol 2000, 1(5):398-401.

19. Ferwerda B, McCall MB, Alonso S, Giamarellos-Bourboulis EJ, Mouktaroudi M, Izagirre N, Syafruddin D, Kibiki G, Cristea T, Hijmans A, Hamann L, Israel S, ElGhazali G, Troye-Blomberg M, Kumpf O, Maiga B, Dolo A, Doumbo O, Hermsen CC, Stalenhoef AF, van Crevel R, Brunner HG, Oh DY, Schumann RR, de la Rua C, Sauerwein R, Kullberg BJ, van der Ven AJ, van der Meer JWV, Netea MG: TLR4 polymorphisms, infectious diseases, and evolutionary pressure during migration of modern humans. Proc Natl Acad Sci U S A 2007, 104(42):16645-16650.

20. Sarir $H$, Henricks PA, van Houwelingen AH, Nijkamp FP, Folkerts G: Cells, mediators and Toll-like receptors in COPD. Eur J Pharmacol 2008, 585(2-3):346-353.

21. Sato K, Yoshimura A, Kaneko T, Ukai T, Ozaki Y, Nakamura H, Li X, Matsumura $H$, Hara $Y$, Ogata $Y$ : A single nucleotide polymorphism in 3 -untranslated region contributes to the regulation of Toll-like receptor 4 translation. J Biol Chem 2012, 287(30):25163-25172.

22. Inoue $Y$, Shimojo N, Suzuki Y, Campos Alberto EJ, Yamaide A, Suzuki S, Arima T, Matsuura T, Tomiita M, Aoyagi M, Hoshioka A, Honda A, Hata A, Kohno Y: CD14-550 C/T, which is related to the serum level of soluble CD14, is associated with the development of respiratory syncytial virus bronchiolitis in the Japanese population. J Infect Dis 2007, 195(11):1618-1624

23. Levan TD, Michel O, Dentener M, Thorn J, Vertongen F, Beijer L, Martinez FD: Association between CD14 polymorphisms and serum soluble CD14 levels: effect of atopy and endotoxin inhalation. J Allergy Clin Immunol 2008, 121(2):434-440. e431.

24. Yuan FF, Marks K, Wong M, Watson S, de Leon E, Mclntyre PB, Sullivan JS: Clinical relevance of TLR2, TLR4, CD14 and FcgammaRIIA gene polymorphisms in Streptococcus pneumoniae infection. Immunol Cell Biol 2008, 86(3):268-270.

25. Guarner-Argente C, Sanchez E, Vidal S, Roman E, Concepcion M, Poca M, Sanchez D, Juarez C, Soriano G, Guarner C: Toll-like receptor 4 D299G polymorphism and the incidence of infections in cirrhotic patients. Aliment Pharmacol Ther 2010, 31(11):1192-1199.

26. Surbatovic M, Grujic K, Cikota B, Jevtic M, Filipovic N, Romic P, Strelic N, Magic Z: Polymorphisms of genes encoding tumor necrosis factor-alpha, interleukin-10, cluster of differentiation-14 and interleukin-1 ra in critically ill patients. J Crit Care 2010, 25(3):542. e541-548.
27. Zhang $A Q$, Yue CL, Gu W, Du J, Wang HY, Jiang J: Association between CD14 promoter -159C/T polymorphism and the risk of sepsis and mortality: a systematic review and meta-analysis. PLOS One 2013, 8(8):e71237.

28. Masson S, Caironi P, Spanuth E, Thomae R, Panigada M, Sangiorgi G, Fumagalli R, Mauri T, Isgro S, Fanizza C, Romero M, Tognoni G, Latini R, Gattinoni L: Presepsin (soluble CD14 subtype) and procalcitonin levels for mortality prediction in sepsis: data from the Albumin Italian Outcome Sepsis trial. Crit Care 2014, 18(1):R6.

29. Stephens M, Smith NJ, Donnelly P: A new statistical method for haplotype reconstruction from population data. Am J Hum Genet 2001, 68(4):978-989.

30. Kawai T, Akira S: The role of pattern-recognition receptors in innate immunity: update on Toll-like receptors. Nat Immunol 2010, 11(5):373-384.

31. Iwasaki A, Medzhitov R: Regulation of adaptive immunity by the innate immune system. Science 2010, 327(5963):291-295.

32. Arbour NC, Lorenz E, Schutte BC, Zabner J, Kline JN, Jones M, Frees K, Watt $J \mathrm{~L}$, Schwartz DA: TLR4 mutations are associated with endotoxin hyporesponsiveness in humans. Nat Genet 2000, 25(2):187-191.

33. Schmitt C, Humeny A, Becker CM, Brune K, Pahl A: Polymorphisms of TLR4: rapid genotyping and reduced response to lipopolysaccharide of TLR4 mutant alleles. Clin Chem 2002, 48(10):1661-1667.

34. Lorenz E, Mira JP, Frees KL, Schwartz DA: Relevance of mutations in the TLR4 receptor in patients with gram-negative septic shock. Arch Intern Med 2002, 162(9):1028-1032.

35. Hang J, Zhou W, Zhang H, Sun B, Dai H, Su L, Christiani DC: TLR4 Asp299Gly and Thr399lle polymorphisms are very rare in the Chinese population. J Endotoxin Res 2004, 10(4):238-240.

36. Wu MS, Cheng TY, Shun CT, Lin MT, Chen LC, Lin JT: Functional polymorphisms of CD14 and toll-like receptor 4 in Taiwanese Chinese with Helicobacter pylori-related gastric malignancies. Hepatogastroenterology 2006, 53(71):807-810.

37. Fukusaki T, Ohara N, Hara Y, Yoshimura A, Yoshiura K: Evidence for association between a Toll-like receptor 4 gene polymorphism and moderate/severe periodontitis in the Japanese population. J Periodontal Res 2007, 42(6):541-545.

38. Hishida A, Matsuo K, Goto Y, Mitsuda Y, Hiraki A, Naito M, Wakai K, Tajima K, Hamajima N: Toll-like receptor $4+3725$ G/C polymorphism, Helicobacter pylori seropositivity, and the risk of gastric atrophy and gastric cancer in Japanese. Helicobacter 2009, 14(1):47-53.

39. Hishida A, Matsuo K, Goto Y, Naito M, Wakai K, Tajima K, Hamajima N: Combined effect of miR-146a rs2910164 G/C polymorphism and Toll-like receptor $4+3725 \mathrm{G} / \mathrm{C}$ polymorphism on the risk of severe gastric atrophy in Japanese. Dig Dis Sci 2011, 56(4):1131-1137.

40. Zhou L, Wei B, Xing C, Xie H, Yu X, Wu L, Zheng S: Polymorphism in 3 -untranslated region of toll-like receptor 4 gene is associated with protection from hepatitis $B$ virus recurrence after liver transplantation. Transpl Infect Dis 2011, 13(3):250-258.

41. Miedema KG, te Poele EM, Tissing WJ, Postma DS, Koppelman GH, de Pagter AP, Kamps WA, Alizadeh BZ, Boezen HM, de Bont ES: Association of polymorphisms in the TLR4 gene with the risk of developing neutropenia in children with leukemia. Leukemia 2011, 25(6):995-1000.

42. Mansur A, von Gruben L, Popov AF, Steinau M, Bergmann I, Ross D, Ghadimi M, Beissbarth T, Bauer M, Hinz J: The regulatory toll-like receptor 4 genetic polymorphism rs11536889 is associated with renal, coagulation and hepatic organ failure in sepsis patients. J Transl Med 2014, 12:177.

43. Zhao L, Bracken MB: Association of CD14-260 (-159) C > T and asthma: a systematic review and meta-analysis. BMC Med Genet 2011, 12:93.

44. Kim EJ, Chung WC, Lee KM, Paik CN, Jung SH, Lee BI, Chae HS, Choi KY: Association between toll-like receptors/CD14 gene polymorphisms and inflammatory bowel disease in Korean population. J Korean Med Sci 2012 , 27(1):72-77

45. Wang Z, Hu J, Fan R, Zhou J, Zhong J: Association between CD14 gene C-260 T polymorphism and inflammatory bowel disease: a meta-analysis. PLoS One 2012, 7(9):e45144

46. Azzam N, Nounou H, Alharbi O, Aljebreen A, Shalaby M: CARD15/NOD2, CD14 and Toll-like 4 Receptor Gene Polymorphisms in Saudi Patients with Crohn's Disease. Int J Mol Sci 2012, 13(4):4268-4280. 
47. D'Avila LC, Albarus MH, Franco CR, Aguiar BB, Oliveira JR, Dias FS, Alho CS Effect of CD14-260C > T polymorphism on the mortality of critically ill patients. Immunol Cell Biol 2006, 84(4):342-348.

48. Fallavena PR, Borges TJ, Paskulin DD, Paludo FJ, Goetze TB, de Oliveira JR, Nobrega OT, Dias FS, Alho CS: The influences of CD14-260C > T polymorphism on survival in ICU critically ill patients. Immunol Invest 2009, 38(8):797-811.

49. Liu HH, Hu Y, Zheng M, Suhoski MM, Engleman EG, Dill DL, Hudnall $M$, Wang J, Spolski R, Leonard WJ, Peltz G: Cd14 SNPs regulate the innate immune response. Mol Immunol 2012, 51(2):112-127.

doi:10.1186/s12881-014-0123-4

Cite this article as: Wang et al:: The association of polymorphisms of TLR4 and CD14 genes with susceptibility to sepsis in a Chinese population. BMC Medical Genetics 2014 15:123.

\section{Submit your next manuscript to BioMed Central and take full advantage of:}

- Convenient online submission

- Thorough peer review

- No space constraints or color figure charges

- Immediate publication on acceptance

- Inclusion in PubMed, CAS, Scopus and Google Scholar

- Research which is freely available for redistribution 